IZA DP No. 2465

Real Wage Cyclicality in Italy

Fei Peng

W. Stanley Siebert

November 2006 


\title{
Real Wage Cyclicality in Italy
}

\author{
Fei Peng \\ University of Birmingham Business School \\ W. Stanley Siebert \\ University of Birmingham Business School \\ and IZA Bonn
}

Discussion Paper No. 2465
November 2006

\author{
IZA \\ P.O. Box 7240 \\ 53072 Bonn \\ Germany \\ Phone: +49-228-3894-0 \\ Fax: +49-228-3894-180 \\ E-mail: iza@iza.org
}

\begin{abstract}
Any opinions expressed here are those of the author(s) and not those of the institute. Research disseminated by IZA may include views on policy, but the institute itself takes no institutional policy positions.

The Institute for the Study of Labor (IZA) in Bonn is a local and virtual international research center and a place of communication between science, politics and business. IZA is an independent nonprofit company supported by Deutsche Post World Net. The center is associated with the University of Bonn and offers a stimulating research environment through its research networks, research support, and visitors and doctoral programs. IZA engages in (i) original and internationally competitive research in all fields of labor economics, (ii) development of policy concepts, and (iii) dissemination of research results and concepts to the interested public.
\end{abstract}

IZA Discussion Papers often represent preliminary work and are circulated to encourage discussion. Citation of such a paper should account for its provisional character. A revised version may be available directly from the author. 
IZA Discussion Paper No. 2465

November 2006

\section{ABSTRACT}

\section{Real Wage Cyclicality in Italy*}

This paper analyzes the cyclical behaviour of male real wages in Italy using the European Community Household Panel 1994-2001. We distinguish between job stayers (remaining in the same job), and within- and between-company job movers. Stayers are the large majority. We find stayers in Northern Italy to have high cyclicality of real wages, higher in fact than the US and the UK. The Northern cyclicality is significant for all sub-samples (except for public sector workers), and higher in small firms, the private sector, and for temporary workers, as expected. In contrast, we find little wage cyclicality for any sub-group in the Centre-South, even for workers in small private sector firms. Evidently, labour markets in the North of Italy operate much more competitively than in the Centre and South.

JEL Classification: E32, J31, K31

Keywords: real wage cyclicality, job stayers, Italy, ECHP

Corresponding author:

W. S. Siebert

Business School

Birmingham University

University House

Edgbaston

Birmingham B15 2TT

United Kingdom

E-mail: w.s.siebert@bham.ac.uk

\footnotetext{
* The European Community Household Panel for Italy is used with the permission of Eurostat, which bears no responsibility for the analysis or interpretations presented here. We are grateful to the Economic and Social Research Institute (Dublin) for training in the use of the ECHP dataset, and for valuable comments from Alex De Ruyter, Marco Ercolani, Nicholas Horsewood, Peter Sinclair and M. Davide Parrilli, and other participants at seminars at the University of Birmingham
} 


\section{REAL WAGE CYCLICALITY IN ITALY}

\section{Introduction}

This paper analyses real wage adjustment over the business cycle using panel micro data for Italy 1994-2001, which have recently become available from the European Community Household Panel. Italy has a regulated economy which forms an interesting contrast to the more flexible economies of the US and the UK which have been extensively studied (starting with Bils 1985 for the US; see also Devereux and Hart 2006 for the UK). The Italian labour market has been performing badly, with only about 55\% of Italians in the 15-64 age range in employment during the 1990s, compared to over $70 \%$ in the UK and US (OECD, 2004). The 2001 Italian White Paper on reform of the labour market (EIRO, 2001) sees a "local” wage policy, with “more space for decentralised bargaining”, as part of the cure. Put simply, it may be that nationally bargained wages cannot adjust downwards enough in response to adverse shocks to avoid job losses (see also Ochel, 2005, for a similar argument for Germany). In this study, we aim to give a factual basis to the debate, making comparisons with the well-developed research results for the UK and the US.

In fact, Italy's wage-setting institutions have a dual nature. On the one hand, the Constitution makes collective agreements generally binding (OECD, 2004, 149), and the courts use minimum wages from sectoral agreements to determine whether wages conform to constitutional requirements. Also, Italy's1993 tripartite incomes policy agreement (EF, 1993) has had a centralising effect - indeed, Limosani's (2004) recent model of Italian unemployment simply assumes no regional differentiation in wages. On the other hand, the debate on bargaining reform (EIRO, 2004) reveals nearly 300 sectoral wage agreements registered with the National Statistical Institute, which indicates flexibility. Moreover, Italy's “schisms” (Kenworthy, 2001) between north and south, and regular and irregular economies must limit the reach of any centralised policy. On balance, however, Italy's wage-setting institutions have been characterised as distinctly coordinated and centralised (OECD, 2004, Table 3.5). An indication of the power of central wage-setting is Italy's relatively high, $80 \%+$, collective bargaining coverage. Whether, in fact, there is effective central power is something our regressions will test.

Our approach offers two advances which have not so far been applied to Italian data. First, we use data from a panel of individuals, rather than aggregate data. Panel data are necessary to remove compositional biases from the wage measure. Such bias arises because the composition of the workforce changes over the cycle. Over the cycle, more unskilled workers become employed in expansion and pull the aggregate average wage downwards. The converse occurs in recession. Thus, an aggregate wage series is countercyclically biased, and our panel technique avoids this bias.

Second, following Devereux and Hart (2006), we make a threefold distinction between job stayers (remaining in the same job over the year), internal movers (i.e., within-company movers), and external movers (between-company). Each of these three groups is likely to have a different wage reaction to business cycle conditions. As regards the broad distinction between movers and stayers, research has found that real wages are more procyclical for those who change companies, than for those who do not (Bils 1985 and Shin 1994 for the US, Hart 2006 and Devereux and Hart 2006 for the UK). Beaudry and DiNardo's (1991) implicit contracting model can explain this result. Risk-averse employees may be shielded from productivity shocks, implying smoother wage 
adjustments for job stayers. In contrast, workers who are forced to change jobs have no access to insurance, and their new wage rates are likely to be more dependent on spot market conditions, leading to higher fluctuations in wages. ${ }^{1}$

As for wage movements within the company, Reder's (1955) theory of promotion/demotion along a firm's internal job ladders shows that wages can change for internal movers even while job stayers' wages - set perhaps by collective agreement - are unresponsive to the cycle. In fact, for the UK, Devereux and Hart (2006) find that wages for job stayers are quite flexible, so that internal job moves play a minor role in wage cyclicality. (Nickell and Quintini’s (2003) finding that around 20\% of job stayers experienced nominal wage cuts annually during the 1990s, also points to high UK wage flexibility.) However, the Italian results might be different, given the greater importance of collective agreements. Our threefold distinction is important therefore.

The remainder of this paper is organised as follows. In section II, we present our estimation methodology, and in Section III, we describe the data. Section IV examines the basic predictions of theoretical models by region and compares our results with other findings. In Section V, we test the robustness of our results by firm size, public-private sector, and permanent-temporary contract type. The final section concludes.

\section{Estimation}

The standard decomposition of wage growth (Solon et al, 1997, and Devereux and Hart, 2006), distinguishing between jobstayers and internal and external movers is:

$$
\begin{aligned}
\mathrm{E}(\Delta \ln \mathrm{W}) & =\left(1-\mathrm{P}_{\mathrm{W}}-\mathrm{P}_{\mathrm{B}}\right) \mathrm{E}\left(\Delta \ln \mathrm{W}_{\mathrm{S}}\right)+\mathrm{P}_{\mathrm{W}} \mathrm{E}\left(\Delta \ln \mathrm{W}_{\mathrm{W}}\right)+\mathrm{P}_{\mathrm{B}} \mathrm{E}\left(\Delta \ln \mathrm{W}_{\mathrm{B}}\right) \\
& =\mathrm{E}\left(\Delta \ln \mathrm{W}_{\mathrm{S}}\right)+\mathrm{P}_{\mathrm{W}} \mathrm{E}\left(\Delta \ln \mathrm{W}_{\mathrm{W}}-\Delta \ln \mathrm{W}_{\mathrm{S}}\right)+\mathrm{P}_{\mathrm{B}} \mathrm{E}\left(\Delta \ln \mathrm{W}_{\mathrm{B}}-\Delta \ln \mathrm{W}_{\mathrm{S}}\right)
\end{aligned}
$$

where $\mathrm{P}_{\mathrm{W}}$ and $\mathrm{P}_{\mathrm{B}}$ denotes the proportion of workers changing jobs within and between companies, and $\mathrm{E}\left(\Delta \ln \mathrm{W}_{\mathrm{S}}\right), \mathrm{E}\left(\Delta \ln \mathrm{W}_{\mathrm{W}}\right)$, and $\mathrm{E}\left(\Delta \ln \mathrm{W}_{\mathrm{B}}\right)$ is the expected wage growth of job stayers $(\mathrm{S})$, internal movers $(\mathrm{W})$ and external movers $(\mathrm{B})$.

Differentiating equation (1) with respect to the change in the unemployment rate, $\Delta \mathrm{u}$, provides a decomposition of total wage cyclicality:

$$
\begin{aligned}
\partial \mathrm{E}(\Delta \ln \mathrm{W}) / \partial(\Delta \mathrm{u}) & =\partial \mathrm{E}\left(\Delta \ln \mathrm{W}_{\mathrm{S}}\right) / \partial(\Delta \mathrm{u}) \\
& +\mathrm{P}_{\mathrm{W}}\left[\partial \mathrm{E}\left(\Delta \ln \mathrm{W}_{\mathrm{W}}-\Delta \ln \mathrm{W}_{\mathrm{S}}\right) / \partial(\Delta \mathrm{u})\right] \\
& +\mathrm{P}_{\mathrm{B}}\left[\partial \mathrm{E}\left(\Delta \ln \mathrm{W}_{\mathrm{B}}-\Delta \ln \mathrm{W}_{\mathrm{S}}\right) / \partial(\Delta \mathrm{u})\right] \\
& +\partial \mathrm{P}_{\mathrm{W}} / \partial(\Delta \mathrm{u})\left[\mathrm{E}\left(\Delta \ln \mathrm{W}_{\mathrm{W}}-\Delta \ln \mathrm{W}_{\mathrm{S}}\right)\right] \\
& +\partial \mathrm{P}_{\mathrm{B}} / \partial(\Delta \mathrm{u})\left[\mathrm{E}\left(\Delta \ln \mathrm{W}_{\mathrm{B}}-\Delta \ln \mathrm{W}_{\mathrm{S}}\right)\right]
\end{aligned}
$$

The first term is the wage response of job stayers; the second term defines the incremental effect of wage cyclicality on internal movers relative to stayers, and the third term defines the incremental effect of wage cyclicality on external movers relative to stayers. The last two terms represent the cyclicality of the probability of internal and external job changes. Since these terms are small, we concentrate on the wage responses.

\footnotetext{
${ }^{1}$ Using the PSID and CPS, Beaudry and DiNardo (1991) find empirical evidence to support their model. Grant (2003) also finds support for Beaudry and DiNardo (1991) using the NLS. Barlevy (2001) provides an alternative hypothesis that the strong wage procyclicality of job changers is due to compensating wages. Workers who voluntarily switch jobs in booms enter temporary jobs with unemployment risk and receive compensating higher wages in the new jobs.
} 
Our empirical work uses the now-standard two-step estimation procedure (beginning with Solon et al 1994). The two-step procedure is designed to get round the Moulton (1986) problem of using individual characteristics alongside the aggregate unemployment cyclical indicator. ${ }^{2}$ Thus, in step 1, we use all our 17,000 individual observations to estimate the wage change equation for an individual $i$ at time $t$. This equation is given by:

$$
\Delta \ln w_{i t}=\alpha_{0}+\alpha_{1} A g e_{i t}+\sum_{t=1}^{T} \phi_{0 t} D_{t}+\sum_{t=1}^{T} \phi_{1 t} M_{\text {Wit }} D_{t}+\sum_{t=1}^{T} \phi_{2 t} M_{B i t} D_{t}+\varepsilon_{i t}
$$

where $\mathrm{w}_{\mathrm{it}}$ is the real hourly wage rate, Age $_{i t}$ is a cubic in age, $\mathrm{D}_{\mathrm{t}}$ denotes a year dummy, and $\varepsilon_{i t}$ is a random error term. $\mathrm{M}_{\mathrm{Wit}}$ denotes a dummy variable for internal movers, and $\mathrm{M}_{\mathrm{Bit}}$ is a dummy variable for external movers.

In step 2, the three sets of dummy variable estimates $\hat{\phi}_{j t}(\mathrm{j}=0,1,2)$ are regressed on the change in the preceding year's unemployment rate $\left(\Delta \mathrm{u}_{\mathrm{t}-1}\right)$ and a linear time trend. Here, we only have time series variation - in our case 8 years. Again, this problem is standard (for example, Shin, 1994, has 12 time series observations), and the solution adopted, which we follow, is to use weighted least squares where the weights are the numbers of individuals observed in a given year. Our 8 year period covers almost the full business cycle that began in Italy in 1992. This equation is given by:

$$
\hat{\phi}_{j t}=\delta_{j 0}+\delta_{j 1} \Delta u_{t-1}+\delta_{j 2} \text { Year }_{t}+v_{j t} . \quad(\mathrm{j}=0,1,2)
$$

Equation (4) links directly to the decomposition of wage cyclicality in (2). Using $\hat{\phi}_{0 t}$ in equation (4), the estimated value of $\delta_{01}$ gives the cyclical wage response of job stayers. Using $\hat{\phi}_{1 t}$ and $\hat{\phi}_{2 t}$ in equation (4), we obtain estimates of $\delta_{11}$ and $\delta_{12}$; that is the incremental wage effects of within- and between-company movers relative to stayers.

\section{Data Description}

The European Community Household Panel (ECHP) is a harmonised cross-national longitudinal survey focusing on household income and living conditions. The surveys in Italy were carried out as eight waves from 1994 to 2001. Approximately 7,100 households i.e. 17,700 adults aged 16 years and over were interviewed in the first wave. Individuals who were members of a household in the first wave are followed over time. Then, for the last wave in 2001, there were still about 5,600 households left in this dataset.

For this research, we formed an unbalanced panel of approximately 6,000 male workers, each observed for about 4.5 years. In concentrating on males, we are following the literature (e.g., Devereux, 2001; Shin and Solon, 2006). In fact, female participation is low in Italy, so that our female sample is only half that of males. The small sample would give difficulties when we analyse sub-groups (e.g., small firms in the South).

Our main dependent variable is the individual's hourly wage, which we compute as the ratio of annual gross labour income to annual hours of work. Gross annual

\footnotetext{
${ }^{2}$ Moulton (1986) shows that individuals in the same year/area will share some common component of variance that is not entirely attributable either to their measured characteristics (e.g., gender and age) or to the aggregate unemployment rate in the year/area. In this case, the error component in OLS regression will be positively correlated across people in the same year/area, causing the estimated standard error of the unemployment effect to be downward biased.
} 
earnings are composed of normal wages, 13th and 14th salary, and extra payments for overtime, holiday pay, earnings from an additional job, and other earnings not specified separately. Hence, the corresponding annual working hours are also from the main and any additional job including overtime. ${ }^{3}$ We deflate wages using the Consumption Price Index. Our main independent variable is the lagged unemployment rate, which we measure from the ECHP as the weighted unemployment rate for the worker's region, either North, or Centre-South ${ }^{4}$.

The main concern about our wage variable is likely to be the measurement of hours. In particular, workers may report contract hours rather than actual hours worked, causing reported hours to remain overly steady from year to year. Devereux (2001) calls this the "clumping" problem, giving an understatement of the cyclicality of hours, and consequently an overstatement of the cyclicality of hourly wages. We have checked our hours variable carefully. We find, on average, only $65 \%$ of job stayers had the same reported weekly hours in two adjacent years (the proportion varied between $56 \%$ for $1996 / 97$ and $71 \%$ for $1999 / 2000$ ). Thus, there seems to be significant variation in reported hours from year to year, especially given that true hours are likely to remain constant for most stayers. Furthermore, hours show some procyclicality, which is reasonable. Thus, we take it that the bias from misreporting of hours is not large.

We use three questions from the ECHP to distinguish between job stayers and movers: the starting year of the current job for the employee, his residential area, and his movement in job status (supervisory, intermediate or non-supervisory etc.). We identify a job stayer as an employee who has no change in starting year, working region or job status. If the starting year or working region change, we take it that the employee has moved out of the company i.e., is a between-company mover. Then, a within-company mover is a worker who has no change in starting year and working region, but has some changes in job status

Table 1 presents summary statistics of male workers in the North and CentreSouth, for the key variables underlying the subsequent analysis. Our sample covers 6363 males who are employed in the year and can provide clear information about job movement. The North and Centre-South seem quite similar, apart from the fact that more in the North are working in the private sector (82\%) than in the Centre-South (64\%). There is a somewhat higher proportion working in small business in the Centre-South ${ }^{5}$, but very few temps in either region.

\section{(Table 1 around here)}

As regards wage levels, we see that public sector wages are higher than private, and also that public sector wages do not differ between the regions (the log wage equals 2.63 in both). We see here the force of centralised collective agreements. However,

\footnotetext{
${ }^{3}$ This wage measure in the ECHP is close to the measures used in Solon et al (1994) and Devereux (2001) for the United States. However, this broad wage measure may show higher procyclicality than a basic wage measure excluding earnings from bonuses, additional job and overtime, which is used in Devereux and Hart (2006) for the UK.

${ }^{4}$ The ECHP provides information for 11 regions. We categorise the Nord Ovest, Nord Est, Lombardia and Emilia-Romagna as the North. All the remaining regions, including the Centro, we define as "CentreSouth”. This division gives about $40 \%$ of the sample classified as North (Table 1 ).

${ }^{5}$ The ECHP can only provide categorised firm size. Hence, we choose those with less than 20 employees as small firms and those with more than 20 employees as big firms.
} 
private sector wages do differ between regions, being higher in the North. This difference is particularly marked for small firms, whose wages are $18 \%$ higher in the North than the Centre-South. Evidently, collective agreements have not stopped wages falling in the South, though perhaps they have prevented them falling far enough ${ }^{6}$. Evidence on this aspect is shown by the wage change data at the bottom of the table. In fact, as can be seen, stayers and internal movers have similar wage changes in the North and Centre-South, but external movers do not. The Centre-South shows a negative real wage change for external movers $\left(\Delta \ln W_{B}=-8.8 \%\right)$. Thus, it seems external movers are more likely to be involuntarily laid off in the South, and the large loss in wages for movers points to the possibility of above-equilibrium wages for stayers.

\section{Basic Empirical results}

Baseline results are reported in Table 2. We confine attention to the unemployment change coefficients, estimated in step two of our regressions, i.e., equation (4). The table suggests markedly different labour markets in the North and Centre-South. Firstly, wages of job stayers in the North show significant and higher flexibility (-3.60) than those in the Centre-South (-1.40). This result could be explained on the White Paper arguments above, if centralised wage bargaining binds more in the low-wage Centre-South (but see below).

Secondly, internal movers in the North show significant and higher wage flexibility than their counterparts in the Centre-South. Thus, there appears to be more internal wage flexibility in the North as well, with employers using internal promotion/demotion to adjust wages according to the business cycle, along the lines of the Reder (1955) model.

Finally, real wages of external movers show signs of a procyclical pattern in both regions, though with a more pronounced effect in the Centre-South (point estimate, -7.65). This result could fit in with the explanation mentioned above, that Southern wages are above equilibrium. If within-firm wages were pushed up somehow, the burden of flexibility would be placed on the external movers.

\section{(Table 2 around here)}

Equation (2) expresses overall wage cyclicality in terms of three main wage parts. We are also in a position to evaluate their separate contributions. By using tables 1 and 2, together with equation (2), we find that the dominant part of overall wage procyclicality is from wage responses of job stayers. Wage responses of internal and external movers only account for a small part of the overall wage cyclicality. ${ }^{7}$

Making comparisons with the UK and the US, Table 2 shows that while wage cyclicality for the Centre-South appears to be almost zero, that for Northern Italy is, if

\footnotetext{
${ }^{6}$ The above results are simple averages. However, the picture is similar when we introduce controls. We ran wage regressions with a North=1 dummy, controlling for quadratic experience, quadratic tenure, 3 education dummies, a part-time dummy, 18 industry dummies, 20 occupation dummies and a year trend. In the regression for the public sector, the dummy for North is still only 0.01 , and insignificant. For private small firms, the dummy indicates a 13.6\% wage advantage for the North. For private sector large firms, the dummy indicates a $10.6 \%$ wage advantage for the North.

${ }^{7}$ For example, the wage cyclicality of job stayer in the North, i.e. $\partial \mathrm{E}\left(\Delta \ln \mathrm{W}_{\mathrm{s}}\right) / \partial(\Delta \mathrm{u})$ is -3.6 , while the corresponding part of the incremental wage effects of internal movers, i.e. $P_{W}\left[\partial E\left(\Delta \ln W_{W}-\Delta \ln W_{S}\right) / \partial(\Delta u)\right]$ and external movers, i.e. $\mathrm{P}_{\mathrm{B}}\left[\partial \mathrm{E}\left(\Delta \ln \mathrm{W}_{\mathrm{B}}-\Delta \ln \mathrm{W}_{\mathrm{S}}\right) / \partial(\Delta \mathrm{u})\right]$ are -0.53 and -0.14 respectively. Thus, the wage cyclicality of job stayers is the most important part of the overall wage cyclicality.
} 
anything, higher than the US and UK. Thus, for male stayers in the US, Solon et al (1994) find an elasticity of -1.2 for male stayers, and Shin and Solon (2006) find a similar -1.5. Also for the US, Devereux (2001) finds -1.09 for male job stayers. For the UK, Devereux and Hart (2006) find -1.83 for male stayers. In order to test the robustness of our basic results, we now estimate wage cyclicality for sub-groups within our sample. ${ }^{8}$

\section{Results by firm size, sector and contract type}

We now contrast small and large firms, public and private sectors, permanent and temporary workers. We would expect more flexibility in small firms, which may take a more laissez faire approach to industry wage agreements. Also small firms (under 15 employees in the legislation) are less likely to be covered by employment protection laws (Boeri and Jimeno 2005), meaning less shielding of job stayers and accordingly more wage flexibility. Because of small firm importance, more flexibility is likely to be found in the private than the public sector. Moreover, for the public sector, as noted above (Table 1) the higher wages set by centralised wage bargaining will constrain flexibility. Finally, we would expect temporary workers to have flexible wages.

(Table 3 around here)

Table 3 shows considerable wage flexibility for workers in the North, regardless of the ways in which we split the sample. By contrast, as the first row shows, even for small firms in the Centre-South, there is no significant result for wage cyclicality. The next panels of the table break the sample down, in the effort to discover what drives the differences between small and large firms. The permanent-temporary distinction shows permanent workers' wages to be quite inflexible in both regions, and temporary workers wages to be quite flexible.

The next panel takes the private-public distinction. We see that there in no significant wage flexibility in the public sector in either region, as might be expected. Since the public sector contains mainly large firms, the implication is that the significant wage flexibility shown for large firms (in the North, at least), is driven by the private sector.

The final panel of the table considers the private sector only, and we see indeed that there is significant wage flexibility for large private sector firms in the north (stayers coefficient, -2.97). As might be expected, most wage flexibility is still exhibited by small firms, both for stayers (-7.58), and for internal movers. However, for the Centre-South, even for small private sector firms, there remains no evidence of wage flexibility for any group.

A question for further research is why there should be such low wage flexibility in small businesses in the Centre-South. As we have already noted from Table 1, wage levels for small businesses in the Centre-South are much lower than in the North, so market forces are having some impact. However, wage changes do not reflect the market. Where, then, do small businesses in the Centre-South achieve their needed cyclical

\footnotetext{
${ }^{8}$ Another test is to estimate the coefficients with "balanced" samples (the 750 male workers in the north and 1231 male workers in the south who have valid wage and job movement observations in every year of the sample period) as in Solon et al (1994) and Shin (1994). The results, $-4.3 \%$ for male job stayers in the North and $-2.03 \%$ for the South are close to results from our complete sample. But, the significance levels decrease because of the small sample size.
} 
flexibility? The answer does not lie in any greater procyclicality of hours, since neither in the North nor is the Centre-South hours significantly procyclical. ${ }^{9}$ If we consider a broad industrial breakdown, the most important small-firm sector is services, and it is here that the Centre-South is inflexible compared to the North (by contrast, Southern manufacturing achieves some wage flexibility ${ }^{10}$ ). Therefore, the question becomes why small business services in the Centre-South have inflexible wages. The answer could lie in the larger shadow economy in the South (Dell'Aringa, 2002), with labour unrecorded by the ECHP moving into and out of jobs in business services, but more research is needed.

\section{Conclusions}

Following the methodology of earlier studies of the USA and the UK, we are able to make a fine distinction between wage movements of job stayers, of internal job movers, and external job movers. Job stayers are most important, and we find (male) stayers in Northern Italy to have high cyclicality of real wages, while those in Southern Italy do not. This difference remains however we cut the samples - whether by firm-size, or privatepublic sector, or permanent-temporary contract. In the North, wage cyclicality of job stayers is significant for all sub-samples (except for public sector workers), though predictably higher in small firms, the private sector, and for temporary workers. There is also some wage cyclicality of internal job movers. There is never much wage cyclicality for any sub-group in the Centre-South, even for small private sector firms.

The results provide qualified support for the role of institutional wage setting in limiting real wage flexibility in Italy. The similarly inflexible real wages of public sector workers in both the North and Centre-South can be ascribed to centralised wage bargaining. In addition, the greater wage flexibility of small firms than large (in the North) might also be due to this factor, plus the lower employment protection of small firm workers. On the other hand, the wage inflexibility even of small private sector firms in the Centre-South is puzzling. Wage levels for this sub-category are lower than in the North, suggesting that centralised wages are not a constraint. Similarly, moving into and out of these firms (external movers) does not have strong wage consequences, as would be expected if rents were available to incumbent workers. Yet, while this puzzle is one that will require further research to resolve, our results show that it is real. Whatever the reason, our results suggest that labour markets in the North of Italy operate much more competitively than in the Centre and South. .

\footnotetext{
${ }^{9}$ This statement is true for both stayers and others, and whether we consider total weekly hours, or weekly hours worked on the main job only.

${ }^{10}$ For private sector small business, the job stayer coefficient for services is $-11.2 *$ for the North $(n=2223)$ and -1.61 for the south $(n=4158)$. For manufacturing, the coefficient is -0.69 for the North ( $n=1981)$, and $3.36 *$ for the South $(n=2495)$
} 
Table 1: Means and Standard Deviations, Males in the ECHP 1994-2001

(Standard deviations in parentheses)

\begin{tabular}{|c|c|c|c|c|}
\hline \multicolumn{3}{|c|}{ Variable } & North & $\begin{array}{l}\text { Centre } \\
\text {-South }\end{array}$ \\
\hline \multirow[t]{4}{*}{ Proportions of total observations: } & \multicolumn{2}{|l|}{ Private sector } & 0.820 & 0.640 \\
\hline & \multicolumn{2}{|c|}{ Permanent contracts } & 0.945 & 0.878 \\
\hline & \multicolumn{2}{|c|}{ Workers in small firms $(<20)$} & 0.590 & 0.639 \\
\hline & \multicolumn{2}{|c|}{ Full-time workers } & 0.980 & 0.965 \\
\hline \multirow{3}{*}{$\begin{array}{l}\text { Worker movement: proportions } \\
\text { of total observations: }\end{array}$} & \multicolumn{2}{|l|}{ Job stayers } & 0.755 & 0.764 \\
\hline & \multicolumn{2}{|l|}{ Internal movers } & 0.176 & 0.168 \\
\hline & \multicolumn{2}{|c|}{ External movers } & 0.069 & 0.067 \\
\hline \multirow[t]{4}{*}{ Mean wage $(\ln W)$ : } & \multicolumn{2}{|c|}{ Overall } & $\begin{array}{c}2.41 \\
(0.64)\end{array}$ & $\begin{array}{c}2.35 \\
(0.68)\end{array}$ \\
\hline & \multicolumn{2}{|l|}{ Public sector } & $\begin{array}{c}2.63 \\
(0.47)\end{array}$ & $\begin{array}{c}2.63 \\
(0.49)\end{array}$ \\
\hline & \multirow[t]{2}{*}{ Private sector: } & Large firm & $\begin{array}{c}2.46 \\
(0.52)\end{array}$ & $\begin{array}{l}2.39 \\
(0.55)\end{array}$ \\
\hline & & Small firm & $\begin{array}{c}2.18 \\
(0.75)\end{array}$ & $\begin{array}{l}2.00 \\
(0.77)\end{array}$ \\
\hline \multirow[t]{3}{*}{ Wage changes $(\Delta \ln W)$ : } & \multicolumn{2}{|c|}{ Job stayers $\left(\Delta \ln \mathrm{W}_{\mathrm{S}}\right)$} & $\begin{array}{l}0.048 \\
(0.41)\end{array}$ & $\begin{array}{l}0.049 \\
(0.38)\end{array}$ \\
\hline & \multicolumn{2}{|c|}{ Internal movers $\left(\Delta \ln \mathrm{W}_{\mathrm{W}}\right)$} & $\begin{array}{l}0.060 \\
(0.41)\end{array}$ & $\begin{array}{l}0.041 \\
(0.40)\end{array}$ \\
\hline & \multicolumn{2}{|c|}{ External movers $\left(\Delta \ln \mathrm{W}_{\mathrm{B}}\right)$} & $\begin{array}{l}0.047 \\
(0.70)\end{array}$ & $\begin{array}{l}-0.088 \\
(0.79)\end{array}$ \\
\hline \multirow{2}{*}{\multicolumn{3}{|c|}{$\begin{array}{l}\text { Number of individuals } \\
\text { Number of observations }\end{array}$}} & 2,489 & 3,874 \\
\hline & & & 10,712 & 17,445 \\
\hline
\end{tabular}

Table 2: Real hourly wage and unemployment changes, ECHP 1994-2001

(coefficients on $\Delta \mathrm{u}_{\mathrm{t}-1}$ from wage change equation 4)

\begin{tabular}{lccc}
\hline Region & Job stayers & $\begin{array}{c}\text { Incremental effect } \\
\text { for internal movers }\end{array}$ & $\begin{array}{c}\text { Incremental effect } \\
\text { for external movers }\end{array}$ \\
\hline North & $-3.60^{*}$ & $-3.03^{* * *}$ & -2.01 \\
& $(2.24)$ & $(1.11)$ & $(14.78)$ \\
\hline \multirow{2}{*}{ Centre-South } & -1.40 & -0.30 & $-7.65^{* *}$ \\
& $(1.29)$ & $(1.51)$ & $(3.55)$ \\
\hline
\end{tabular}

Notes: Standard errors are in parentheses. $* * *, * *$ and $*$ denote significance at $1 \%, 5 \%$ and $10 \%$ levels for two-tail tests. There are 17,716 individual observations in the first stage (6947 for the north and 10,769 for the south), and 7 country-wide weighted observations in the second stage.. 
Table 3 Real wage and unemployment changes, by firmsize, contract and sector

(coefficients on $\Delta \mathrm{u}_{\mathrm{t}-1}$ from wage change equation 4)

\begin{tabular}{|c|c|c|c|c|c|c|}
\hline & \multicolumn{3}{|c|}{ North } & \multicolumn{3}{|c|}{ Centre-South } \\
\hline & Job stayers & $\begin{array}{c}\text { Incremental } \\
\text { effect for } \\
\text { internal movers }\end{array}$ & $\begin{array}{c}\text { Incremental } \\
\text { effect for } \\
\text { external movers }\end{array}$ & Job stayers & $\begin{array}{c}\text { Incremental } \\
\text { effect for } \\
\text { internal movers }\end{array}$ & $\begin{array}{c}\text { Incremental } \\
\text { effect for } \\
\text { external movers }\end{array}$ \\
\hline \multirow[t]{2}{*}{ Small firm $(<20)$} & $-5.96 *$ & $-8.16^{*}$ & -6.65 & -2.20 & 0.02 & -4.78 \\
\hline & (3.68) & (3.92) & (12.28) & $(1.52)$ & $(2.28)$ & (4.39) \\
\hline \multirow[t]{2}{*}{ Large firm $(>=20)$} & $-2.69 *$ & $-3.10^{*}$ & 7.55 & -0.87 & -0.79 & -6.78 \\
\hline & $(1.60)$ & $(2.04)$ & $(24.57)$ & $(1.19)$ & $(1.68)$ & $(10.94)$ \\
\hline \multirow[t]{2}{*}{ Permanent workers } & -2.22 & $-4.71 * * *$ & -4.72 & -1.72 & -0.16 & -3.55 \\
\hline & $(1.78)$ & $(1.25)$ & $(9.09)$ & $(1.15)$ & $(1.10)$ & $(4.20)$ \\
\hline \multirow[t]{2}{*}{ Temporary workers } & $-26.83^{* *}$ & 12.12 & 10.89 & -0.81 & $-12.07 * *$ & -3.05 \\
\hline & $(10.20)$ & $(26.94)$ & $(35.08)$ & $(2.62)$ & $(5.44)$ & $(4.57)$ \\
\hline \multirow[t]{2}{*}{ Private Sector } & $-3.89 *$ & $-3.53 *$ & 0.50 & -1.62 & -1.03 & -6.57 \\
\hline & $(2.10)$ & $(1.86)$ & (13.55) & $(1.50)$ & $(1.97)$ & $(4.49)$ \\
\hline \multirow[t]{2}{*}{ Public Sector } & -1.77 & -1.37 & 8.48 & -1.27 & 0.51 & -3.64 \\
\hline & $(1.91)$ & $(2.91)$ & $(44.43)$ & $(1.04)$ & $(2.18)$ & $(5.70)$ \\
\hline \multirow{3}{*}{$\begin{array}{l}\text { Private sector } \\
\text { (perm }+ \\
\text { temp): }\end{array}$} & $-7.58^{*}$ & $-6.81^{*}$ & -5.72 & -3.84 & 2.72 & 8.42 \\
\hline & $(4.84)$ & $(4.30)$ & (11.96) & $(4.08)$ & (3.35) & $(9.87)$ \\
\hline & $\begin{array}{l}-2.97 * \\
(2.00)\end{array}$ & $\begin{array}{c}-4.11 \\
(3.04)\end{array}$ & $\begin{array}{c}10.70 \\
(12.60)\end{array}$ & $\begin{array}{c}-3.46 \\
(3.26)\end{array}$ & $\begin{array}{c}4.57 \\
(3.51)\end{array}$ & $\begin{array}{c}-11.18 \\
(26.72)\end{array}$ \\
\hline
\end{tabular}

Notes: see notes to Table 2. 


\section{References}

Barlevy, G. (2001). "Why Are the Wages of Job Changers So Procyclical?” Journal of Labor Economics, 19:837-878.

Beaudry, P and J DiNardo. (1991). "The Effect of Implicit Contracts on the Movement of Wages Over the Business Cycle: Evidence from Micro Data.” Journal of Political Economy, 99: 665-688.

Bils, M. (1985). "Real Wages Over The Business Cycle: Evidence From Panel Data.” Journal of Political Economy, 93: 666-689.

Boeri, T and Jimeno, J. (2005). "The Effects Of Employment Protection: Learning From Variable Enforcement.” European Economic Review, 49: 2057-2077

Dell’Aringa, C. (2002). 'The Italian Labour Market: Problems and Prospects.” Discussion Paper in New Dimensions in Italian Public Policy Lecture Series, Oxford: St Anthony's College, http://www.sant.ox.ac.uk/esc/esclectures/aringa.htm

Devereux, P. (2001). "The Cyclicality of Real Wages Within Employer-Employee Matches.” Industrial and Labor Relations Review, 54: 835-850.

Devereux, J. and R A. Hart. (2006). "Real Wage Cyclicality of Job Stayers, WithinCompany Job Movers, and Between-Company Job Movers.” Industrial and Labor Relations Review, 60: 105-119.

EIRO. (2001). Government Presents White Paper on Labour Market. Dublin: European Industrial Relations Observatory Online, http://www.eiro.eurofound.eu.int.

EIRO. (2004). Debate on Bargaining Reform Delays Dialogue. Dublin: European Industrial Relations Observatory Online, http://www.eiro.eurofound.eu.int.

EF. (1993). Agreement of 23 July 1993. Italy, Dublin: European Foundation for the Improvement of Living and Working Conditions, http://www.eurofound.eu.int/emire/italy/agreementof23july1993.

Grant, D. (2003). “The Effect of Implicit Contracts on the Movement of Wages over the Business Cycle: Evidence from the National Longitudinal Surveys.” Industrial and Labour Relations Review, 56: 393-408.

Hart, R A. (2006). "Worker-Job Matches, Job Mobility and Real Wage Cyclicality.” Economica, 73: 287-98.

Kenworthy, L. (2001). "Wage-setting Measures: A Survey and Assessment”. World Politics, 54: 57-98

Limosani, M. (2004). "Beyond Institutions: Widening Unemployment Differentials in Italy.” Labour, 8: 503-514.

Moulton, B R. (1986). "Random Group Effects and the Precision of Regression Estimates.” Journal of Econometrics, 32: 385-397.

Nickell, S and G Quintini. (2003). "Nominal Wage Rigidity and the Rate of Inflation.” Economic Journal, 113:762-781.

Ochel, W. (2005). "Decentralizing Wage Bargaining in Germany - A Way to Increase Employment?” Labour, 19 (1): 91-121.

OECD. (2004). Employment Outlook, Paris: Organisation for Economic Cooperation and Development.

Reder, M W. (1995). “The Theory of Occupational Wage Differentials.” American Economic Review, 45: 833-52.

Shin, D. (1994). “Cyclicality of Real Wages Among Young Men.” Economics Letters, 46: 137-142.

Shin, D and Solon, G. (2006). "New Evidence On Real Wage Cyclicality Within Employe r-Employee Matches.” NBER Working Paper 12262. 
Solon, G, R. Barsky, and J A Parker. (1994). "Measuring the Cyclicality of Real Wages: How Important Is Composition Bias?” Quarterly Journal of Economics, 109: 126.

Solon, G, W Whatley, and A Stevens. (1997). "Wage Changes and Intrafirm Job Mobility over the Business Cycle: Two Case Studies.” Industrial and Labor Relations Review, 50: 402-415. 